\title{
Determining of Risk Factors of Low-Birth weight Babies in Padang, West Sumatra Using Logistic Regression Analysis
}

\author{
Hazmira Yozza ${ }^{1}$, Ferra Yanuar $^{2}$, Izzati Rahmi $^{3}$, Nadya Putri Alisya ${ }^{4}$ \\ Universitas Andalas Padang, hazmirayozza@sci.unand.ac.id ${ }^{l}$ \\ Universitas Andalas Padang, ferrayanuar@sci.unand.ac.id ${ }^{2}$ \\ Universitas Andalas Padang, izzatirahmihg@ gmail.com ${ }^{3}$ \\ Universitas Andalas Padang, nadyaalisya3011@gmail.com ${ }^{4}$
}

doi: https://doi.org/10.15642/mantik.2020.6.2.135-141

\begin{abstract}
Abstrak. Angka Kematian Bayi adalah salah satu indikator yang digunakan untuk mengukur kualitas hidup dari suatu bangsa. World Health Organization (WHO) menyatakan bahwa salah satu penyebab utama dari kematian bayi adalah bayi yang dilahirkan dengan berat badan rendah (BBLR). Upaya untuk menurunkan kejadian BBLR dapat dilakukan mulai pada masa prenatal dengan memonitor faktor resiko yang secara nyata mempengaruhi kejadian BBLR tersebut. Penelitian ini bertujuan untuk mengidentifikasikan faktor resiko yang secara nyata mempengaruhi kejadian BBLR di Kota Padang, Sumatera Barat. Analisis data dilakukan dengan menggunakan Analisis Regresi Logistik terhadap data ibu melahirkan yang berdomisili di Kota Padang. Disimpulkan bahwa, faktor yang berpengaruh nyata dari kejadian BBLR adalah pertambahan berat badan ibu selama hamil, paritas, jarak dengan kelahiran sebelumnya, banyaknya masalah kesehatan selama hamil dan jenis kelamin bayi.
\end{abstract}

Kata kunci: Bayi berat lahir rendah; Faktor resiko; Analisis regresi logistik

\begin{abstract}
Infant mortality is one of the indicators used to measure the quality of life of a nation. The World Health Organization (WHO) stated that one of the main causes of infant mortality is the low birth weight (LBW). Efforts to reduce the incidence of LBW can be done by monitoring risk factors that influence the occurrence of LBW in the prenatal phase. This study aims to identify factors that significantly influence the incidence of LBW babies in Padang, West Sumatra, Indonesia. The analysis was carried out by using Logistic Regression Analysis on the data of maternal births domiciled in Padang, West Sumatra, Indonesia. It was concluded that variables that significantly affect the incidence of LBW are maternal weight, parity, distance from a previous birth, problems during pregnancy, and babies' gender.
\end{abstract}

Keywords: Low birth weight babies; Risk factors; Logistic regression analysis

How to cite: H. Yozza, F. Yanuar, I. Rahmi, N. and P. Alisya, "Determining of Risk Factors of LowBirthweight Babies in Padang, West Sumatra Using Logistic Regression Analysis”, J. Mat. Mantik, vol. 6, no. 2, pp. 135-141, October 2020. 


\section{Introduction}

Infant mortality is one indicator of the quality of health service and -broadly speaking- the quality of life of a nation. High infant mortality rate is related to the inadequate health services in a country. The World Health Organization (WHO) estimates 4,1 million babies in 2017 died before completing the first year of age. More than twothirds of these deaths occur in the early neonatal period [1]. Generally, these occur due to low birth weight, that is commonly referred as the incidence of Low Birth Weight (LBW).

WHO defines LBW as weight at birth is less than 2500 grams. This continues as a globally health problem. WHO estimated that $15 \%-20 \%$ of all births, or more than 20 million births a year, worldwide are low birth weight. Almost all cases $(96.5 \%)$ occur in developing countries [2]. Babies born with LBW have a risk of death 4 times higher than those with normal weight [3],

Based on the Indonesian Health and Demographic Survey (SKDI) conducted by The National Family Planning Board together with Central Bureau of Statistics of Republic of Indonesia, The Indonesian Ministry of Health, and USAID, in 2012, the neonatal mortality rate in Indonesia was 20 per 1000 live births which tended to stagnate a decade earlier. In 2017, SKDI noted that this number decreased to 15 deaths per 1000 births [4]. Despite the decline, the Infant Mortality Rate (IMR) in Indonesia is still very high when compared to IMR in other ASEAN countries. Using data sourced from The World Bank obtained from the website www.theworldbank.org, Indonesia's IMR in 2017 is 1.3 - 9.7 times of IMR in other ASEAN countries. High IMR, both in early neonatal deaths and in infants less than a year old, 35\% are due to LBW [5].

Efforts to reduce perinatal death can be done by suppressing the number of births weighing less than 2500 grams and this can be done by providing supervision for all pregnant women and correcting the factors that affect fetal and neonatal safety [6]. In the initial stages, supervision can be carried out by identifying risk factors for LBW incidents and the causes of LBW incident increasement. It is necessary to evaluate policies related to health services for pregnant women and infants.

Many risk factors can affect the incidence of LBW. From a search conducted on several research results, there are factors that influence the occurrence of LBW including pregnant women at the age of less than 20 years or more than 35 years, the distance of pregnancy is too short (less than 2 years), mothers with previous LBW conditions, doing physical work several hours without rest, socioeconomic, poor nutritional status and smokers, drug users and alcohol. Other factors which can also be suspected to influence are parity, the amount of weight gain during pregnancy, prenatal care and haemoglobin concentration [7], [8], [9], [10], [11]. In addition, several studies have shown that there is a fairly close relationship between the incidence of LBW and premature birth [12].

Most of researcher conducted to determine influencing variables (also called risk factors) of LBW used bivariate analysis, most of them by using chi-square analysis. In this research, we used Logistic Regression Analysis, where the influence of variables is determined simultaneously. In this method, the modeling is carried out by considering the relationship among predictors. In addition, by using this approach, the magnitude of the effect of a variable on LBW events can be determined.

This research aims to identify risk factors which are significantly affected by the incident of the LBW in Padang, West Sumatra and its effect on the incident of the LBW baby. The study is limited to single births and to women who live in the city of Padang, West Sumatra. 


\section{Theoretical Framework}

\subsection{Low-birth Weight Baby}

Low birth weight (LBW) babies are babies with birth weights of less than 2500 grams regardless of gestational period. Birth weight is the weight of a baby weighed within 1 (one) hour after birth [13]. Babies born with a weight of 2000 - 2499 grams are 10 times higher risk of dying than babies born with a body weight of 3000-3499 grams [8]. Other research claimed that the risk is 4,1 times higher [3]. There are 3 forms of LBW namely: LBW premature babies, LBW small babies for pregnancy and LBW premature babies and small babies for pregnancy.

\subsection{The Logistic Regression Analysis}

Regression analysis in statistics is a statistical method that aims to determine the causal relationship between response variables with one or more predictors. When the response variable is binary data that has only two possible outcomes, ordinary regression analysis can no longer be used to model the relationship between these variables. One approach that can be used in this condition is logistic regression analysis.

Logistic regression analysis is one of the regression analysis to model the causal relationship between one or more predictors (also called risk factors) and binary response variable that has only two possible outcome, i.e success and failure [14]. This method involves a logit transformation of response data. The logistic regression model that describes the relationship between response variable and $k$ risk factors, $X_{1}, X_{2}, \ldots, X_{k}$ is

$\operatorname{logit}(\pi(\boldsymbol{x}))=\log \left(\frac{\pi(\boldsymbol{x})}{1-\pi(\boldsymbol{x})}\right)=\beta_{0}+\beta_{1} X_{1 i}+\beta_{2} X_{2 i}+\cdots+\beta_{k} X_{k i}+\varepsilon_{i}$

where $\pi(\boldsymbol{x})$ denotes the probability of success $(\mathrm{P}(\mathrm{Y}=1)$ at specified value of $X_{1}, X_{2}, \ldots, X_{k}, \beta_{i}{ }^{\prime} s$ denotes model parameters. The parameter $\beta_{j}$ refers to the effect of $X_{j}$, controlling the other $X$ 's [14]. Standard method to estimate the logistic regression parameters is the maximum likelihood estimation. It is based on finding the estimates that maximize likelihood for observed data under the chosen model [15].

Interpretation of the effect of risk factors $X_{j}$ on response variables in logistic regression uses the odds ratio. For model (1), odds are defined as

$$
\frac{\pi(x)}{1-\pi(x)}=e^{\beta_{0}+\beta_{1} X_{1 i}+\beta_{2} X_{2 i}+\cdots+\beta_{k} X_{k i}}
$$

This relationship provides the interpretation of $\beta_{j}$; For a risk factor, odds at $\mathrm{x}+1$ is the equal to odds at $\mathrm{x}$ multiply by $e^{\beta_{j}}$. Ratio between odss at $\mathrm{x}+1$ and odds at $\mathrm{x}$ is usually called odds ratio $(\mathrm{OR})$ and formulated as $\mathrm{OR}=e^{\beta_{j}}$. This ratio measures the influence of each risk factors that is the odds is multiply $e^{\beta_{j}}$ for every increase of $x_{j}$ and at fixed level of other x's. When $\beta_{j}=0, e^{\beta_{j}}=1$, the odds do not change as $\mathrm{x}$ change. This means that the probability of success is independent of $X$. In logistic regression, Wald test uses to test the hyphotesis $H 0: \beta_{j}=0$ or to assess the significance of an individual regression coeficient. This test based on Wald statistic which is asymptotically distributed as a chisquare distribution [14].

\section{Methods}

\subsection{Population and Sample}

Population in this research is post-portum women and their babies in Padang, West Sumatra. Sample is consist's of postpartum mothers who were cured at several hospitals/maternity hospitals in Padang, West Sumatra. 


\subsection{Data and Variables}

This research used primary data collected from postpartum women in several health facilities in Padang. Observation is limited to mothers with single births. The response variable measured is the birth weight of the baby which is then used as the basis for grouping babies into two groups, namely:

a. Low birth weight group, namely babies with birth weights of less than 2500 grams

b. Normal birth weight group, i.e. babies with birth weights equal or more than 2500 grams

Predictors or risk factors that are assumed to influence the incidence of LBW babies are:

a. Mother age $\left(\mathrm{X}_{1}\right)$ in years

b. Mother education $\left(\mathrm{X}_{2}\right)$, is a categorical variable with categories: low education, middle education and higher education

c. Weight gain during pregnancy $\left(\mathrm{X}_{3}\right)$, in kgs

d. Mother's pre-pregnancy weight $\left(\mathrm{X}_{4}\right)$, in kgs

e. Mother Hemoglobin level $\left(\mathrm{X}_{5}\right)$,

f. Parity $\left(\mathrm{X}_{6}\right)$,

g. Birth spacing to previous birth $\left(\mathrm{X}_{7}\right)$, in years

h. Number of health problems during pregnancy $\left(\mathrm{X}_{8}\right)$. This is a categorical variable. Based on this variable, observation can be categorized into: no-problem, one problem, more than one problem.

i. Frequency of prenatal visit $\left(\mathrm{X}_{9}\right)$

j. Sex of the baby $\left(\mathrm{X}_{10}\right)$. This is a categorical variable with male and female category. Male baby was treated as reference category

\subsection{Data Analysis}

Data were analyzed using logistic regression analysis, a regression method that aims to model the relationship between risk factors and binary response that has only two possible categories, "success" and "failure". In this research, the incidence of LBW is denoted as success. In the logistic regression analysis, the relationship between response variable and predictor variables is described by the logistic regression model (Model (1)). The logistic regression model constructed to describe the relationship between the incidence of LBW and it's assumed risk factors is:

$$
\operatorname{logit}(\pi(\boldsymbol{x}))=\log \left(\frac{\pi(\boldsymbol{x})}{1-\pi(\boldsymbol{x})}\right)=\beta_{0}+\beta_{1} X_{1 i}+\beta_{2} X_{2 i}+\cdots+\beta_{10} X_{10 i}+\varepsilon_{i}
$$

In Model (3), $\pi(x)$ denotes the probability of having a LBW baby.

At the first stage of the analysis, all risk factors were included in the model. Based on the initial model, Wald test was conducted to examine the significance of the effect of each risk factor on LBW event. In the next step, a new model is reconstructed by only involving variables that have a significant effect. Finally, odds ratio resulted, $e^{\widetilde{\beta}_{j}}$ is used to estimate risk factors' effect on the incidence of LBW

\section{Result and Discussion}

In this study, there were 10 variables that are assumed to influence LBW events, namely maternal age, maternal education, maternal weight gain during pregnancy, maternal weight before pregnancy, hemoglobin levels in maternal blood, parity, distance from previous births, number of health problems that occur during pregnancy, the number of prenatal visits and the sex of the baby. 
By using logistic regression analysis conducted on mothers giving birth to a single baby who lives in Padang, West Sumatra, an initial model is obtained. Following table shows the result of significance test of variables influence to LBW baby incidences.

Table 1. Test Results of the Significance of Independent Variables

\begin{tabular}{clc}
\hline Variable & \multicolumn{1}{c}{ Label } & p-value \\
\hline $\mathrm{X}_{1}$ & Age & 0,971 \\
$\mathrm{X}_{2}$ & Maternal education & \\
$\mathrm{Z}_{21}$ & Low education & 0,950 \\
$\mathrm{Z}_{22}$ & Middle education & 0,496 \\
$\mathrm{X}_{3}$ & Weight gain & 0,882 \\
$\mathrm{X}_{4}$ & Maternal pre-pregnancy weight & $0,048^{*}$ \\
$\mathrm{X}_{5}$ & Haemoglobin level & 0,614 \\
$\mathrm{X}_{6}$ & Parity & $0,013 *$ \\
$\mathrm{X}_{7}$ & Birth spacing to previous birth & $0,010^{*}$ \\
$\mathrm{X}_{8}$ & Number of problems during pregnancy & \\
$\mathrm{Z}_{81}$ & 1 problem & 0,123 \\
$\mathrm{Z}_{82}$ & $>$ 1 problem & $0,017 *$ \\
$\mathrm{X}_{9}$ & Prenatal visits & 0,295 \\
$\mathrm{X}_{10}$ & Sex of the baby & $0,027^{*}$ \\
\hline variable significantly influence the incidence of LBW baby at $\alpha=5 \%$ & \\
& &
\end{tabular}

Based on the significance test conducted on a model involving all independent variables, it was concluded that, at significant level of $\alpha=5 \%$, only maternal weight before birth, parity, distance from previous birth, many problems during pregnancy, and the sex of the baby significantly affected the incidence of LBW. For many problems, the dummy variable that influences the LBW occurrence is a dummy variable for more than 1 problem.

In the next step, we constructed new model by only involving these influential variables. Maximum likelihood method was used to found estimated coefficients that maximize likelihood function. By using maximum likelihood estimation implemented at SPSS statistical software, this following model is produced.

$\operatorname{Logit}\left(p_{i}\right)=0,245-0,132 X_{4 i}-2,992 X_{6 i}-0,938 X_{7 i}+5,415 X_{8 i}+3,947 X_{10 i}$

Interpretation of the effect of each $\mathrm{Xj}$ variable on LBW events is done through the odds ratio (OR) value, which is obtained from the value of $e^{\beta_{j}}$. The odds ratio values for all independent variables entered into the second model are shown in the following table.

Tabel 2. Odds Ratio (OR)

\begin{tabular}{clr}
\hline Variable & \multicolumn{1}{c}{ Label } & $e^{\beta_{j}}$ \\
\hline $\mathrm{X}_{4}$ & Pre-pregnancy weight & 0,877 \\
$\mathrm{X}_{6}$ & Parity & 0,050 \\
$\mathrm{X}_{7}$ & Birth spacing to previous birth & 0,392 \\
$\mathrm{Z}_{82}$ & $>$ 1 problem & 24,754 \\
$\mathrm{X}_{10}$ & Sex of the baby & 5,783 \\
\hline
\end{tabular}

From this table can be seen that odd ratio is less than 1 for three variables, i,e, prepregnancy weight, parity and birth spacing. It means that the increase of these variables has effect to reduce the risk to have LBW baby. The increase of number of problems during pregnancy has effect to increase the risk of having LBW baby

The odd ratio of pre-pregnancy weight is 0,877 , means that an increase in maternal weight before pregnancy by $1 \mathrm{~kg}$ will reduce the risk of LBW incidence 0.877 times. Parity is the number of times that a womens has given birth to a fetus with a gestational age of 24 weeks or more, regardless of whether the child was born alive or stillborn. In this research, the odds ratio of parity (X6) is 0,050 . It is concluded that the risk of LBW will drop to 0.050 times for subsequent child births. Table 2 also shows that the odd ratio 
of X7 (birth spacing to previous pregnancy) is 0,392 . This term refers to time from one birth to the next pregnancy. From the odd ratio shown in the Table 2, it is concluded that a 1 year increase in birth spacing from previous births will reduce the risk of giving birth to a LBW baby by 0.392 times

It is also known that the risk of LBW will increase to 24,754 times when there is a problem during pregnancy. Since male baby is treated as reference category, $\mathrm{OR}=5,783$ means that the risk of LBW occurrence for female babies is greater 5,783 time compared to male babies.

\section{Conclusions}

Initially, there were 10 factors assumed to influence the incidence of LBW babies in Padang, West Sumatra. After analyzing the data with logistic regression analysis, i.e. it can be concluded that the factors that significantly influence LBW events are maternal pre-pregnancy weight, parity, birth spacing to previous births, number problems during pregnancy, and sex of the baby. There is not enough evidence to conclude that maternal age and education, weight gain during pregnancy and number of antenatal visits influence the incidence of LBW babies.

The increase of pre-pregnancy weight, parity, and birth spacing has an effect on reducing the risk of giving birth to LBW babies. On the contrary, the number of problems during pregnancy has an effect on increasing the risk of giving birth to LBW babies. The risk of giving birth to LBW babies is higher for female babies.

\section{References}

[1] The National Development Planning agency, "Laporan Pencapaian Millenium Development Goals Indonesia 2017

[2] World Health Nation, "Global Nutrition Targets 2025: Low Birth Weight Policy Brief," World Health Nation, Geneva, July 2014.

[3] I. P. Sari, Y. Ardillah, and T. A. Widyastuti, "The Determinat of Infant Mortality in Neonatal Period," Jurnal Kesehatan Masyarakat, vol. 12, no. 1, pp. 139-149, July 2016.

[4] The National Family Planning Board, "Survei Kesehatan dan Demografi Indonesia [In Bahasa]," The National Family Planning Board, Jakarta, 2018.

[5] S. Djaja and S. Soemantri, "The Cause of Neonatal Death and The Attributed Health Care System in Indonesia Mortality Study of Household Health Survey," Bul.Penel.Kesehatan, vol. 31, no. 2, pp. 153-156., 2003.

[6] Direktorat Kesehatan RI Bina Kesehatan Masyarakat, "Manajemen Bayi Berat Lahir Rendah (BBLR) untuk Bidan Desa [In Bahasa]," Indonesia Ministry of Health, Jakarta, 2008.

[7] F. Yanuar, H. Yozza, F. Firdawati, I. Rahmi, and A. Zetra, "Applying Bootstrap Quantile Regression for the Construction of a Low Birth Weight Model," Makara Journal of Health Research, vol. 23, no. 2, pp. 90-95, 2019.

[8] S. Badshah, L. Mason, K. McKelvie, L. Payne, and P. J. Lisboa, "Risk Factors for Low Birth Weight in the Public Hospitals at Peshawar NWFP-Pakistan," Biomed Central, vol. 8, pp. 197-205, 2008.

[9] S. Leila, D. Robab, and H. Somaiasadat, "Relationship between Maternal Haemoglobin Concentration and Neonatal Birth Weight," Biomed, pp. 373-376, 2013 .

[10] Tonasih and D. Kumalasary, "Faktor-faktor yang Mempengaruhi Berat Bayi Lahir 
Rendah (BBLR) di Puskesmas Wilayah Kesehatan Harjamukti Kota Cirebon tahun 2018 [In Bahasa]," Jurnal Riset Kebidanan Indonesia, vol. 2, no. 1, pp. 21-27, 2018.

[11] H. S. Joshi et al., "Risk Factors for Low Birth Weight (LBW) Babies and It's Medico Legal Significance," J. Indian Acad. Forensic. Med., vol. 32, no. 2, pp. 212-215, 2016.

[12] L. D. Hailu and D. L. Kebede, "Determinant of Low Birth Weight among Deliveries at a Referral Hospital in Northern Ethiopia," Biomed Research International, vol. 2018, pp. 1-8, April 2018.

[13] World Health Organization, "International Statistical Classification of Disease and Related Health Problems, tenth revision, 2nd edition," World Health Organization, Geneva, 2004.

[14] A. Agresti, An Introduction to Categorical Data Analysis, 2nd ed. New Jersey, USA: John Wiley and Son, 2007.

[15] D. G. Kleinbaum and M. Klein, Logistic Regression: A Self-Learning Text, 3rd ed. New York, USA: Springer-Verlag, 2010. 